\title{
Sprawozdanie z promocji książki Krystyna Śreniowska. Moje życie Łódź, 20 czerwca 2018 r.
}

W dniu 20 czerwca 2018 r. w Sali Rady Wydziału Filozoficzno-Historycznego Uniwersytetu Łódzkiego (UŁ) odbyła się prezentacja książki Krystyna Śreniowska. Moje $\dot{z} y c i e$, opracowanej i przygotowanej do druku przez pracowników Instytutu Historii $(\mathrm{IH})$ - prof. Jolantę Kolbuszewskia i prof. Rafała Stobieckiego, opublikowanej zaś nakładem Wydawnictwa UŁ (Łódź 2018). Wydarzenie to wpisuje się w cykl uroczystości związanych $z$ jubileuszem $70-l e c i a$ istnienia IH UŁ, który przypada w bieżącym roku. W spotkaniu wzięli udział licznie zgromadzeni pracownicy łódzkiej Alma Matris, osoby związane ze środowiskiem demokratycznej opozycji w PRL, które współtworzyła przez lata K. Śreniowska, jej uczniowie, przyjaciele, rodzina oraz przedstawiciele Wydawnictwa UŁ.

Spotkanie otworzył dyrektor IH, prof. dr hab. Dariusz Jeziorny, który powitał serdecznie zebranych i w kilku słowach nakreślił program spotkania. Następnie głos zabrał prof. R. Stobiecki. Nadmienił on na wstępie, że wydawcom wspomnień K. Śreniowskiej przyświecały trzy zasadnicze cele. Po pierwsze, chcieli przypomnieć społeczności akademickiej postać autorki, należącej do pokolenia twórców UŁ. Po drugie, uznali oni prezentowany pamiętnik za ważne źródło do historii tej uczelni. Po trzecie wreszcie, publikacja ta wpisuje się w obchody 70-lecia istnienia IH i w jakimś sensie je publicznie inauguruje. Los zrządził także, że pamiętnik ukazał się w momencie szczególnym - w czasie narastającego kryzysu Universitas oraz gorących sporów o przyszłość akademii i jej miejsce w życiu społecznym.

W dalszej części przemówienia prof. R. Stobiecki przedstawił koleje losu i drogę naukowa autorki wspomnień. Krystyna Maria 


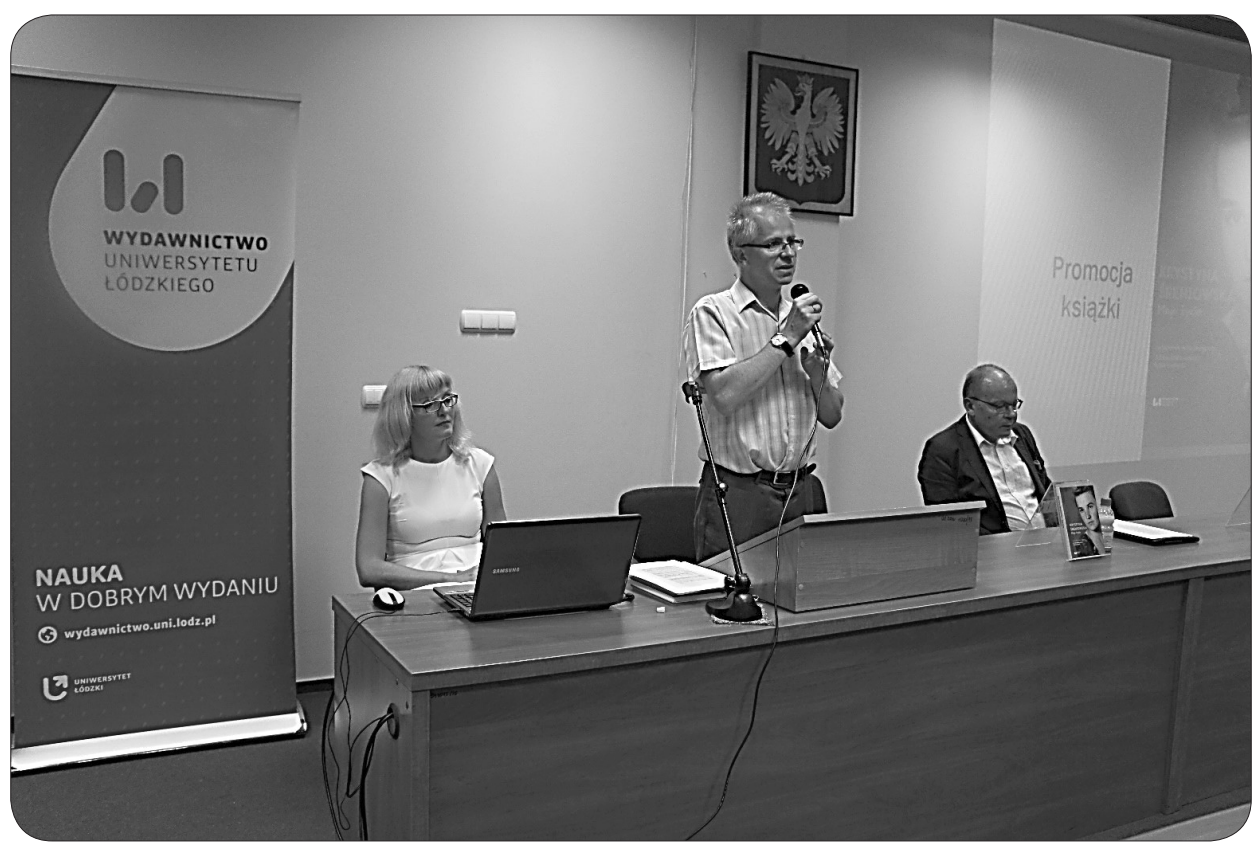

1. Wystapienie dyrektora Instytutu Historii Uniwersytetu Łódzkiego, prof. D. Jeziornego na promocji dzienników K. Śreniowskiej. Za stołem prezydialnym: (od lewej) prof. J. Kolbuszewska, prof. D. Jeziorny, prof. R. Stobiecki.

Fot. M. Karkocha

Śreniowska $z$ domu Oppenauer urodziła się w 1914 r. we Lwowie, w rodzinie inteligenckiej. W roku 1933 ukończyła Prywatne Gimnazjum Żeńskie im. Adama Mickiewicza i wkrótce potem podjęła studia na Uniwersytecie Jana Kazimierza we Lwowie. Studiowała historię, a jednocześnie uzupełniające Studium Dyplomatyczne na Wydziale Prawa tejże uczelni, które ukończyła w 1936 r. Jeszcze przed wybuchem wojny rozpoczęła pracę jako sekretarz w redakcji „Kwartalnika Historycznego”. (Z periodykiem tym współpracowała także po 1945 r., publikując na jego łamach artykuły i recenzje). Po roku pracy przeniosła się do Krakowa, gdzie odbyła początkowo dwumiesięczna bezpłatna praktykę w Bibliotece Muzeum Czartoryskich, a następnie otrzymała podobna posadę w Bibliotece Jagiellońskiej. Wybuch II wojny światowej zastał młodą adeptkę historii we Lwowie. Poszukując pracy, w listopadzie 1939 r. trafiła do znajdującego się pod władzą radziecką Ossolineum, gdzie została zatrudniona w Dziale Rękopisów. W roku następnym wyszła za mąż za Stanisława Śreniowskiego, historyka państwa i prawa, 


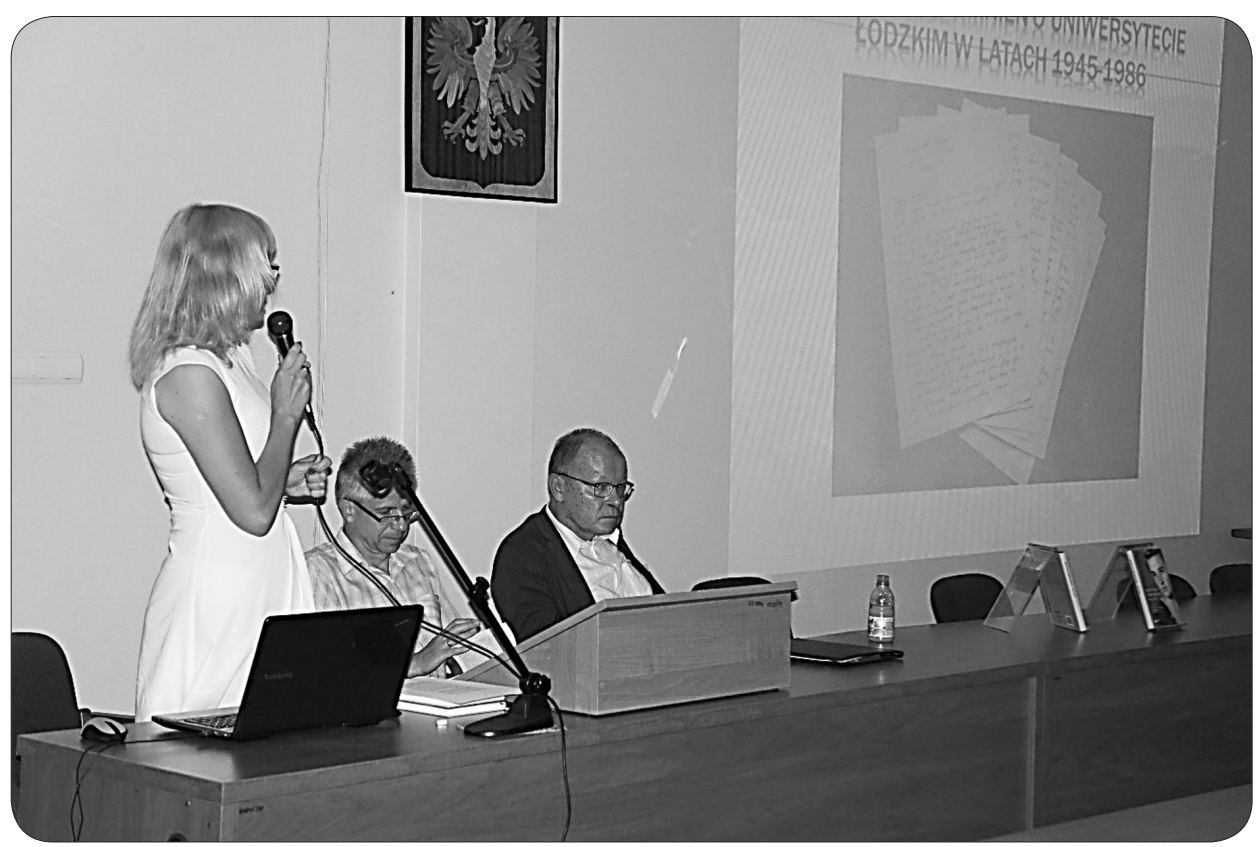

2. Profesor J. Kolbuszewska omawiająca układ i zawartość pamiętników. Fot. M. Karkocha

pracującego na Uniwersytecie Lwowskim. Wiosna 1942 r. młodzi małżonkowie przenieśli się do Krakowa, po czym zamieszkali w Warszawie, gdzie Śreniowska zaangażowała się w tajne nauczanie i pracowała w powstańczej kuchni. W marcu 1945 r. przyszła Pani Profesor zamieszkała $z$ mężem w Łodzi, gdzie otrzymała posadę w Katedrze Historii Społecznej Starożytności i Średniowiecza na nowo wówczas tworzonym Uniwersytecie Łódzkim. $Z$ uczelnią tą związana była przez następne 40 lat, aż do roku 1985, z krótka przerwą na pracę w Instytucie Historii Polskiej Akademii Nauk (w latach 1953-1961). W roku 1956 uzyskała stopień doktora (wówczas kandydata nauk) dzięki pracy o Stanisławie Zakrzewskim. Osiem lat później habilitowała się na podstawie rozprawy o kulcie Tadeusza Kościuszki (Kościuszko. Kształtowanie pogladów na bohatera narodowego 1794-1894, Warszawa 1964) i została docentem. W 1992 r. zaś uzyskała nominację profesorską.

W dorobku naukowym K. Śreniowskiej wyróżnić można kilka wątków tematycznych. Początkowo badała dzieje Polski Jagiellońskiej. Problematyce tej poświęcona była m.in. jej praca magisterska oraz drobne teksty publikowane przed II wojna światowa. Po 


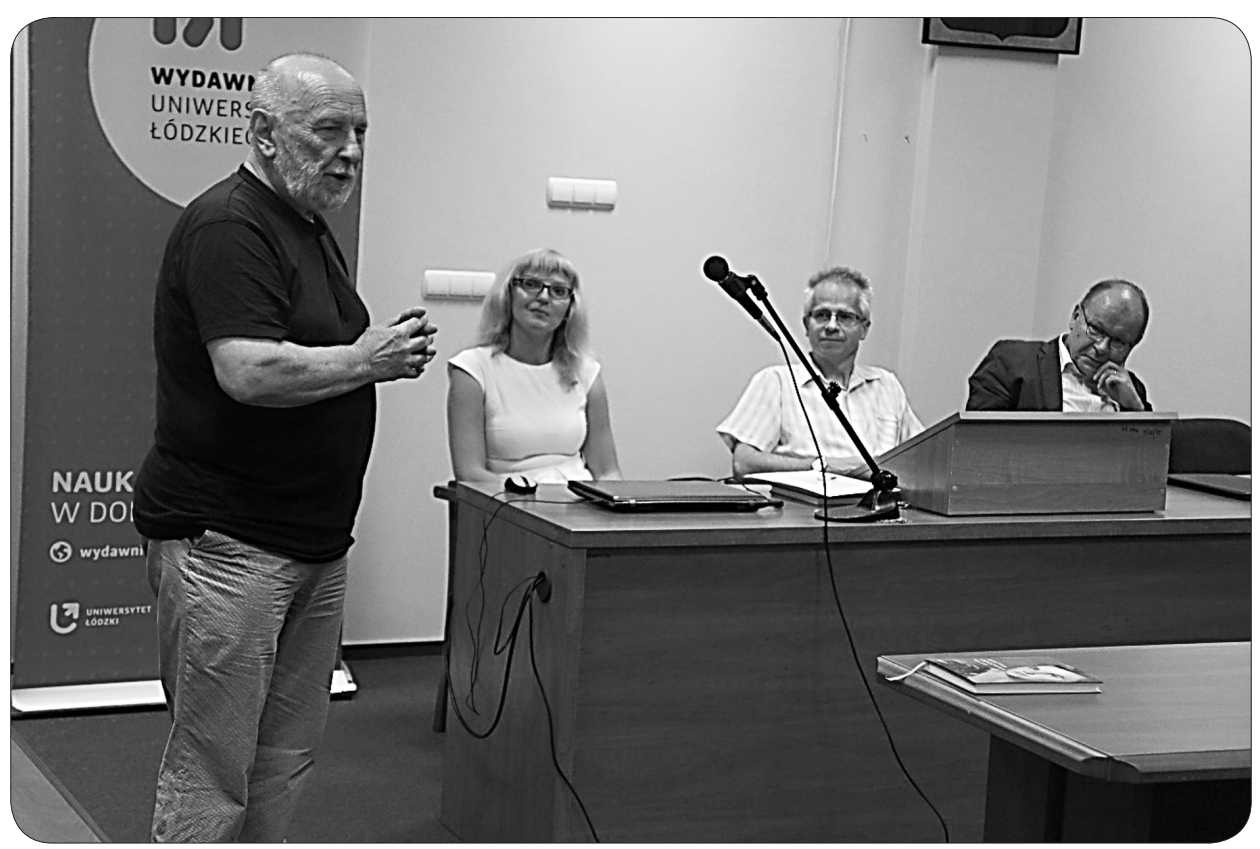

3. Profesor W. Puś wspominajacy K. Śreniowska w czasie debaty. Fot. M. Karkocha

1945 r., kiedy z przyczyn pozanaukowych kontynuowanie badań nad czasami jagiellońskimi okazało się niemożliwe, zwróciła się w kierunku nowej wówczas dyscypliny naukowej, jaką była historia historiografii. $Z$ czasem stała się Śreniowska - obok takich osób, jak Marian Henryk Serejski, Jan Adamus, Franciszek Bronowski, Andrzej Feliks Grabski i Józef Dutkiewicz - czołowa przedstawicielka łódzkiego ośrodka badań historiograficznych. Jej pierwszą większa praca $z$ tej dziedziny była monografia poświęcona Stanisławowi Zakrzewskiemu. W latach sześćdziesiątych i później głównym tematem obecnym w jej twórczości stała się natomiast kwestia pamięci i świadomości historycznej, ze szczególnym uwzględnieniem tradycji kościuszkowskiej. Krystyna Śreniowska zajmowała się także studiami nad historiografią emigracyjna i publikowała artykuły poświęcone zagadnieniom metodologicznym (m.in. kategorii czasu).

Przez lata pracy na Uniwersytecie Łódzkim autorka dziennika dobrze przysłużyła się społeczności akademickiej. W latach 1969-1972 była kierownikiem Studium Zaocznego przy Wydziale Filozoficzno-Historycznym, a w latach 1981-1985 pełniła funkcję 
wicedyrektora IH. Co ważne, była jednym $z$ nielicznych samodzielnych pracowników tego instytutu, którzy otwarcie zaangażowali się w działalność opozycyjną. Wspierała inicjatywy Komitetu Obrony Robotników (KOR), Komitetu Samoobrony Społecznej (KSS) KOR, była członkiem NSZZ „Solidarność”, jako ekspert pomagała studentom w trakcie słynnych strajków $z$ lat 1980/1981, które zakończyły się podpisaniem porozumienia łódzkiego i rejestracja Niezależnego Zrzeszenia Studenckiego.

Krystyna Śreniowska wypromowała dwie rozprawy doktorskie i kilkadziesiąt prac magisterskich. Za swoje osiagnięcia dydaktyczne i organizacyjne została odznaczona m.in. Złotym Krzyżem Zasługi (1973), Medalem Uniwersytetu Łódzkiego „W służbie społeczeństwa i nauki” (1975), Nagrodą Ministerstwa Szkolnictwa Wyższego (1972) oraz Krzyżem Komandorskim Orderu Odrodzenia Polski (2009).

Na zakończenie swojego wystapienia prof. R. Stobieckiego stwierdził, że zapamiętał Panią Profesor jako skromna i odważną kobietę, autorytet moralny dla wielu pokoleń łódzkich historyków. Była ona ceniona przez współpracowników za niezależność, bezinteresowną życzliwość, surowe niekiedy sądy o ludziach, rady, których udzielała. Prezentowany pamiętnik, w przekonaniu prelegenta, w dużym stopniu odzwierciedla ten właśnie jej wizerunek.

Następnie głos zabrała prof. Jolanta Kolbuszewska. Omówiła ona pokrótce konstrukcję książki, materiały, na podstawie których powstała prezentowana publikacja, zarysowała wreszcie potencjał informacyjny, jaki wiąże się ze wspomnieniami Śreniowskiej. Pamiętnik został ukończony w postaci maszynopisu około roku 2000. W tym czasie autorka nanosiła na gotowy już tekst odręczne poprawki i uzupełnienia. Maszynopis został przekazany rodzinie oraz uczniom Pani Profesor - znajdował się w posiadaniu prof. R. Stobieckiego i prof. Zbigniewa Romka $z$ Instytutu Historii Polskiej Akademii Nauk. Wszystkie wersje sa ze soba tożsame i to one stały się podstawą omawianego wydawnictwa. Pamiętnik liczył 104 strony. Chronologicznie obejmował okres od 1914 do początku lat osiemdziesiątych ubiegłego stulecia (cezura zamykajaca był powrót córki K. Śreniowskiej, Barbary, z obozu internowania). Pamiętnik się urywa, jest niedokończony i w takiej też wersji został opublikowany. Tekst wspomnieniowy został zaopatrzony w trojakiego rodzaju przypisy: biograficzne, rzeczowe i bibliograficzne. Uwspółcześniono interpunkcję i ortografię. W kilku przypadkach 
zdecydowano się opuścić niewielkie fragmenty dotyczące personaliów osób żyjących, co do których znalazły się w pamiętniku informacje nieznajdujące potwierdzenia w archiwaliach. Zabieg ten został każdorazowo zaznaczony w tekście.

Odnośnie do zawartości treściowej pamiętnika prof. J. Kolbuszewska stwierdziła, że można na niego spoglądać $z$ wielu perspektyw. Po pierwsze, przede wszystkim jest on kopalnią wiedzy na temat pokolenia inteligencji, które formację intelektualną zdobyło jeszcze w II Rzeczypospolitej, później zaś, w wyniku okrutnych wyroków Historii, zostało wykorzenione ze swych „małych ojczyzn" i musiało odbudowywać życie w nowym, nie do końca znanym i przyjaznym sobie miejscu. Po drugie, wspomnienia Krystyny Śreniowskiej to wspomnienia kobiety, która zdecydowała się na trudna drogę kariery naukowej, kobiety okrutnie doświadczonej przez los (tragiczna śmierć męża w 1957 r.), borykającej się z trudami samotnego macierzyństwa. Po trzecie wreszcie, w oddanym do rąk czytelnika pamiętniku odbijają się dzieje UŁ i łódzkiego środowiska historycznego. Śreniowska patrzyła krytycznie na to środowisko, wyrażając na jego temat zdecydowane i nie zawsze sprawiedliwe sądy.

W dalszej części wystąpienia prof. J. Kolbuszewska stwierdziła, że pamiętnik Moje życie napisany został w sposób specyficzny, odzwierciedlajacy osobowość autorki. Dominuja krótkie zdania, które w sposób dość oszczędny nakreślaja opisywane zdarzenia i sytuacje. Nie znaczy jednak, że w pamiętniku nie można dostrzec emocji. Jest ich cała skala - od miłości, przez przyjaźń, aż do rozczarowania i strachu. Prelegentka wyraziła nadzieję, że książka ta - napisana w ciekawy sposób - zainteresuje nie tylko historyków, historyków historiografii i osoby pracujące w IH UŁ, lecz także przedstawicieli innych dyscyplin naukowych. Na koniec podziękowała obecnym na sali za przybycie, Jego Magnificencji Rektorowi UŁ, prof. dr. hab. Antoniemu Różalskiemu oraz dziekanowi Wydziału Filozoficzno-Historycznego, prof. dr. hab. Maciejowi Kokoszce za wsparcie finansowe, a Wydawnictwu UŁ za druk książki i zorganizowanie jej promocji.

Ostatnim punktem spotkania była dyskusja. Otworzył ja były rektor UŁ, prof. dr hab. Wiesław Puś, snując wspominki o K. Śreniowskiej i wyrażając pochlebne opinie na temat jej pamiętnika. Wśród mówców znaleźli się także dr hab. Jerzy Grobis, emerytowany profesor UŁ, prof. Zbigniew Romek, dawny uczeń Śreniowskiej, 
dr Paweł Spodenkiewicz, działacz KOR internowany w stanie wojennym, oraz Elżbieta Doncbach, działaczka opozycyjna w PRL. Wszyscy oni zapamiętali autorkę wspomnień jako kobietę niezłomną, prawa, łamiącą różne konwencje, będąca na bakier z rzeczywistością, w której przyszło jej żyć, a do tego osobę niezwykle ciepła, życzliwą, troskliwą i oddana sprawie. Profesor Romek stwierdził, że książka Moje życie doskonale odzwierciedla osobowość Śreniowskiej, dr Spodenkiewicz zaś wyraził żal z powodu tego, że nie pozostawiła ona więcej zapisków o charakterze wspominkowym. Przedmiotem dyskusji stała się także kwestia pominięcia na etapie prac redakcyjnych kilku fragmentów tekstu pamiętnika. Profesorowie $Z$. Romek i Krzysztof Lesiakowski z IH UŁ uznali zabieg ten za całkowicie niepotrzebny, mający znamiona cenzury. Podobnego zdania był syn nieżyjącej Pani Profesor - Józef Śreniowski, znany działacz opozycji demokratycznej, członek KOR i członek założyciel KSS KOR, internowany w stanie wojennym, który przemówił jako ostatni. Stwierdził on, że oboje rodzice w pewnym sensie byli naiwni. Wierzyli bowiem, że w Polsce da się zbudować system polski, niebędący kalką systemu radzieckiego. Mówił o tym, że krytyka UŁ przez jego matkę brała się stąd, że inaczej pojmowała ona rolę uczelni wyższej. Chciała widzieć uniwersytet jako miejsce sporu naukowego, nie zaś miejsce, gdzie się jedynie edukuje. To kwestia preferowania odmiennego modelu akademii. Przypomniał również, że Krystyna Śreniowska bardzo nie lubiła ceremonialnych sesji. Była osobą skromną.

Matgorzata Karkocha UNIWERSYTET ŁÓDZKI"

* Wydział Filozoficzno-Historyczny, Instytut Historii, Katedra Historii Nowożytnej, e-mail: malgorzata.karkocha@uni.lodz.pl. 